\title{
Homesick and Migration Effect
}

\author{
Lienggar Rahadiantino ${ }^{1}$, Banu Prasetyo ${ }^{2}$
}

\begin{abstract}
Migration plays an important role in development, especially in the labor economy. This paper reflects the factors that influence structural migration patterns in Indonesia using data from the 2014 Indonesian Family Life Survey (IFLS). We use a probit regression model to determine whether migration without partners and the amount of income affect migration again. by involving control variables, such as the number of migration trips, the distance of the migration location from the area of origin, and area of origin. The results show that a person decides to return to his home area when migrating himself. Migration without other household members causes a person to tend to lose his home. In addition, someone will migrate again when the amount of income received is lower than expected. Sacrificed utility costs cannot cover the burden of dependence on the area of origin. in addition, migrants from Java will choose to migrate again rather than settle.
\end{abstract}

\section{Keywords - migration effect, married man, Indonesia}

\section{INTRODUCTION}

Migration has become one of the most prominent features in improving family welfare in many developing countries. For decades, the movement of poor people in rural areas to cities in search of decent employment opportunities was unlimited. So far, the impact of migration on welfare needs to be analyzed further. For example, the impact of migration often depends on the duration indicator of migration. Basically, migrant households and migration behavior are very heterogeneous. First the duration of the migration from monthly to lifetime. Second, the intensity of migrants differs between households. Third, some households have experienced migration, but have decided to return to their home regions [1]. Evidence shows differences in intensity, duration, and migration behavior have diverse impacts on the welfare of the households left behind [2]. In addition, evidence shows that households with returning immigrants will accumulate savings as other business activities. This can also be caused by high mobility because they selfmigrant or the amount of income received is smaller than expected.

The independent selection of migrants ultimately becomes the core problem of the labor economy considering that migrants are the main actors. To understand the results of migrants, it is necessary to understand that migration is not permanent, but is temporary [3]. The reason migrants return is rarely considered but can be measured economically. The return of migrants can help encourage growth in the area of origin.

Using data from the Indonesian Family Life

${ }^{1}$ Lienggar Rahardiantino, Department of Development Studies, Fakulty of Business and Management Technology, Institut Teknologi Sepuluh Nopember, Surabaya, Indonesia Email: lienggar.rahadian@gmail.com ${ }^{2}$ Banu Prasetyo, Department of Development Studies, Fakulty of Business and Management Technology, Institut Teknologi Sepuluh Nopember, Surabaya, Indonesia Email: bp.signora @gmail.com
Survey (IFLS) we classify the reasons migrants return to their home areas using two categories, 1) migrants return to their area of origin because they migrate themselves "not migrating with other household members", and 2) income received lower than expected. We use the 2014 IFLS migration data by considering the duration of migration in 2000 and 2017. The focus of the study was on male respondents aged 25 - 70 years and already married. The reason for selecting the sample is because it considers the burden of men's responsibilities on the family.

\section{LITERATURE REVIEW}

The concept of The New Economics of Labor Migration (NELM) explains that migration is a household decision based on the concept of maximizing household utilities [4]. Migration helps households access profitable employment as a source of income, reducing liquidity constraints, and covariate risk [5]. The decision, someone will migrate if there is an increase in lifetime income exceeds the cost of migration. According to [6], by coning on the theory of gender roles, women are socialized to give up their own career opportunities in location decisions. The husband as a decision provider pays little attention to the wife's employment opportunities. Therefore, in this condition migration is only done by men, both men who decide to self-migrate or with other household members.

Gender roles in family migration consist of marriage decisions and couples behaving as one entity. From the assumption that partners in the family maximize shared utility, then externalities arising from family decisions can be through transfers [6]. The result of a couple's bargaining efficiency in the family is making binding intertemporal commitments, such as changes in future income through husband migration [7]. The strong correlation between differences in households in income potential considers risk factors. Sources of income benefits differ between the two models, namely income for each partner and differences in income distribution in each region. Therefore, one pair of migrants is considered to be distributing income between the sender and the recipient or income partner. This usually happens when the form of migration itself and the wife are in the area of origin, so the focus is only on the husband's income.

Furthermore, in labor market interactions, the main factor affecting permanent or temporary migration is wages. The higher the wages received, the more likely it is that migrants will stay. Relation of return migration to wages, will migrants enjoy greater wage growth than nonmigrants? Intuitively, migration allows individuals to compete for more jobs and take advantage of job opportunities outside their local labor market. Therefore, employers can consider the willingness of individuals to migrate as a sign of commitment and ambition through remuneration [8]. Migration is driven by regional nonmarket wages which offer utility benefits. 
Every time period, households and companies are at equilibrium. As a result, this cycle cannot increase household utilities or corporate profits, so the basic concept used is migration in response to changes in demand for rising income [8]. Individuals maximize utility flows by moving into new destination areas. Some migrants may not enjoy a positive return on their income. The income of the husband or wife who migrated does not increase, it is even expected to decrease relative to income before migration. Although some research has looked at factors driving migration, it is also important to look at the reasons why migrants decide to return to their home regions.

\section{METHOD}

The effect of migration on homesick using data from wave five of the Indonesia Family Life Survey (IFLS) conducted in the period 2014 and considering 2000 and 2007 to record periods of population movement. IFLS is a longitudinal data obtained from households in Indonesia that provides information on demographics, socioeconomic conditions, and population movement behavior. The sample selection focused on men aged 25-70 years and already married. Married men generally have greater responsibilities. The respondent's age is chosen by considering the individual productive age requirements for work. By considering various characteristics, a sample of 2,179 was obtained.

To examine how the individual pattern decides to return to the area of origin, we consider two variables, such as a) migration with other household members (yes $=1)$ and $b$ ) total monthly income (natural logarithm,). The estimation of this study uses a probit regression analysis model. Next to investigate related variables:

$$
\begin{gathered}
Y_{i j}=\beta_{0}+\beta_{1} F_{i j}+\beta_{2} D_{i j}+\beta_{3} H_{i j}+\varepsilon_{i j} \\
P(Y=1 \mid X)_{i j}=G\left(\beta_{0}+\beta_{1} F_{i j}+\beta_{2} D_{i j}+\beta_{3} H_{i j}+\varepsilon_{i j}\right.
\end{gathered}
$$

Where $Y_{i j}$ is a migrant's decision to return to their hometown. The decision to return to the area of origin uses the binary model, 1 if the individual decides to return to the area of origin, while 0 does not.

Variable control, we do a combination of individual, and household data. $F_{i j}$ is a migration variable, taking into account the migration dummy with other household members, and the natural logarithm of individual income per month. $D_{i j}$ are demographic characteristics (age, education, location of residence and occupational status). The place of residence of origin uses the dummy variable 1 if the individual is from Java, and 0 is not Java.

Furthermore, $H_{i j}$ is a migration characteristic, distance of migration location, duration of migration, how often do migrations.

\section{RESULT AND DISCUSSION}

\section{A. Descriptive Analysis}

Table 1 reports the statistical descriptions for 2,179 individuals in Indonesia. Because this research only focused on men and married in Indonesia, a lot of friction was found. The average age of respondents was 36.25 years. The average length of school is 10.36 years or they quit school during the second grade of High School. Generally, they migrate because of the purpose of getting a job. The average income they receive per month is Rp $2,467,368$, while the average number of household members is 4 people. This shows the immigrants returned to their area of origin before reaching their maximum income. The average total income is still low when compared to the average regional wages of each region.

\section{TABLE 1. DESCRIPTIVE STATISTICS}

\begin{tabular}{lccc}
\hline \multicolumn{1}{c}{ Variable } & Observation & mean & Std. dev \\
\hline $\begin{array}{l}\text { Return } \\
\text { migration }\end{array}$ & 2,179 & 0.527 & .4993 \\
$\begin{array}{l}\text { Migration } \\
\text { with partner }\end{array}$ & 2,179 & 0.490 & 0.500 \\
$\begin{array}{l}\text { Ln income } \\
\text { Age }\end{array}$ & 2,179 & 14.265 & 1.151 \\
$\begin{array}{l}\text { Year of } \\
\text { education }\end{array}$ & 2,179 & 36.256 & 8.560 \\
$\begin{array}{l}\text { Place of } \\
\text { origin }\end{array}$ & 2,179 & 10.631 & 3.874 \\
$\begin{array}{l}\text { Household } \\
\text { size }\end{array}$ & 2,179 & 0.532 & 0.499 \\
$\begin{array}{l}\text { Amount of } \\
\text { trip }\end{array}$ & 2,179 & 4.143 & 1.706 \\
$\begin{array}{l}\text { Distance of } \\
\text { home to } \\
\text { destination }\end{array}$ & 2,179 & 1.978 & 1.528 \\
$\begin{array}{l}\text { Duration of } \\
\text { migration }\end{array}$ & 2,179 & 190.474 & 818.319 \\
$\begin{array}{l}\text { Working } \\
\text { migration }\end{array}$ & 2,179 & 7.353 & 7.188 \\
\hline \hline Source: Authors' calculations based on IFLS data (2014) & & \\
\hline Pon & 2,179 & 0.301 & \\
\hline
\end{tabular}

Because this research looks at whether the driving factor of a migration back to its place of origin, we consider the area of origin. More than half of the respondents are from Java. In addition, whether someone who performs selfmigration will return faster than those who migrate with other household members. Migration without other household members will increase travel expenses to visit their families.

\section{A. Migration with a Partner}

Responding to the problem of homesickness accumulates from time to time, one of which is if they selfmigrate. Migrants who leave their wives will tend to feel homesick faster. Some economic parameters state that the estimated cost of self migration is greater than migration with a partner. The high mobility of migrants visiting families will reduce the level of savings, especially if the distance between the migration location and the area of origin is close. Therefore, a person's chances of retaining employment after returning from their area of origin are very low.

\section{B. Migration and Income Burden}

Table 2 shows the amount of income significantly influences the likelihood of migrants returning to their area of origin. The return of migrants is due to no greater income received than the average minimum wage in Indonesia in 2015. Another finding is that someone who travels more than twice will choose to return rather than settle. His decision, migrants will return after they travel a lot. Many things are behind this decision, one of which 
they did not get financial feasibility on the first trip and will return to their home regions [9]. However, this condition can be contradictory, because those who earn high salaries may also stay longer. In the case of Indonesia, migrants from Java, they will travel only to get a job, then they will return after getting what they want. In addition, the closer distance from the place of origin to the location of migration also encourages a person to choose to return to their area of origin.

\section{CONCLUSION}

Decades of migration have been a major factor in labor problems in Indonesia. This study analyzes the factors that cause migration again. Using the Indonesia Family Life Survey (IFLS) data in 2014 and controlling the duration of migration with data from 2000 and 2007, we obtained a sample of 2,179 male respondents who were married. Data analysis uses probit analysis models to estimate the impact of migration behavior on returning migration. The results prove that migration is not with other family members and the amount of income affects someone's migration back to the area of origin. Migration with a partner has a negative and significant effect indicating that leaving their wives will tend to miss home. This is due to the high mobility of migrants to visit their home regions.

The result of the natural logarithm of income has a negative and significant effect on migration behavior patterns. Migrants will return to their area of origin when the amount of income cannot cover expenses and savings. In addition, migrants coming from Java have a tendency to return to their area of origin rather than settling. This also applies to the distance of residence and destination, the closer the destination will push migrants back to their original area. Likewise for someone who has migrated more than twice. Migrants will return when they feel they have a lot of experience.

In line with development goals, the reduction in the young population due to migration in an area will reduce the quality and productivity of the region itself. Young people have high human resources. It is important for the government to support rural development with a combination of multipurpose technology so as not to lose quality resources because of choosing to work in the city. In addition, there needs to be good cooperation between the government, local stakeholders and the community in the development effort. Future research needs to control changes in regional minimum wages for each region to consider the burden on migrant utilities.

\section{REFERENCE}

[1] A. Kikkawa, T. Matsumoto dan K. Otsuka, "An Inquiry into the Heterogeneous Outcomes of International Migration: Evidence from Rural Households in Bangladesh," The Journal of Development Studies, vol. 55, no. 10, pp. 21062128, 2018.

[2] J. Gibson, D. McKenzie dan S. Stillman, "Accounting for Selectivity and DurationDependent Heterogeneity When Estimating the
Impact of Emigration on Incomes and Poverty in Sending Areas," Economic Development and Cultural Change, vol. 61, no. 2, pp. 247-280, 2013.

[3] C. Biavaschi, "Recovering the counterfactual wage distribution with selective return migration," Labour Economics, vol. 38, pp. 59-80, 2016.

[4] O. Stark dan D. E. Bloom, "The New Economics of Labor Migration," The American Economic Review, vol. 75, no. 2, pp. 173-178, 1985.

[5] M. R. Rosenzweig dan O. Stark, "Consumption Smoothing, Migration, and Marriage: Evidence from Rural India," Journal of Political Economy, vol. 97, no. 4, pp. 905-926, 1989.

[6] M. Foged, "Family migration and relative earnings potentials," Labour Economics, vol. 42, pp. 87-100, 2016.

[7] S. Lundberg dan R. A. Pollak, "Efficiency in Marriage," Review of Economics of the Household, vol. 1, p. 153-167, 2003.

[8] R. Böheim dan M. P. Taylor, "From the dark end of the street to the bright side of the road? The wage returns to migration in Britain," Labour Economics, vol. 14, no. 1, pp. 99-117, 2007.

[9] K. Nakajima, "Homesickness and repeated migration," Applied Economics, 2019. 
The $1^{\text {st }}$ International Conference on Global Development - ICODEV

November $19^{\text {th }}, 2019$, Rectorate Building ITS Campus Sukolilo Surabaya Indonesia

TABLE 2. REGRESSION ANALYSIS OF RETURN MIGRATION

\begin{tabular}{|c|c|c|c|c|}
\hline \multirow[b]{2}{*}{ Variable } & \multicolumn{4}{|c|}{ Return Migration } \\
\hline & $\begin{array}{l}\text { Migration with } \\
\text { Partner }\end{array}$ & $d y / d x$ & Ln Income & $d y / d x$ \\
\hline Migration with partner & $\begin{array}{r}-0.286^{* * *} \\
(0.098)\end{array}$ & -0.113 & & \\
\hline Ln income & & & $\begin{array}{c}-0.069 * \\
(0.038)\end{array}$ & -0.028 \\
\hline Age & $\begin{array}{c}-0.010 * \\
(0.006)\end{array}$ & -0.004 & $\begin{array}{r}-0.014^{* *} \\
(0.006)\end{array}$ & -0.006 \\
\hline Year of education & $\begin{array}{r}0.004 \\
(0.012)\end{array}$ & 0.001 & $\begin{array}{r}0.009 \\
(0.013)\end{array}$ & 0.004 \\
\hline Place of origin & $\begin{array}{r}3.314^{* * * *} \\
(0.095)\end{array}$ & 0.902 & $\begin{array}{r}3.332 * * * \\
(0.095)\end{array}$ & 0.904 \\
\hline Household size & $\begin{array}{r}0.002 \\
(0.026)\end{array}$ & 0.001 & $\begin{array}{r}0.004 \\
(0.026)\end{array}$ & 0.002 \\
\hline Amount of trip & $\begin{array}{r}-0.065^{* *} \\
(0.028)\end{array}$ & -0.026 & $\begin{array}{c}-0.055^{*} \\
(0.028)\end{array}$ & -0.022 \\
\hline Distance of home to destination & $\begin{array}{r}-0.000^{* * * *} \\
(0.000)\end{array}$ & 0.000 & $\begin{array}{r}-0.000 * * \\
(0.000)\end{array}$ & 0.000 \\
\hline Duration of migration & $\begin{array}{r}0.010 \\
(0.007)\end{array}$ & 0.004 & $\begin{array}{r}0.015^{* *} \\
(0.007)\end{array}$ & 0.006 \\
\hline Working migration & $\begin{array}{r}0.033 \\
(0.100)\end{array}$ & 0.013 & $\begin{array}{r}0.063 \\
(0.100)\end{array}$ & 0.025 \\
\hline Cons & $\begin{array}{r}-1.140^{* * *} \\
(0.285)\end{array}$ & & $\begin{array}{r}-0.277 \\
(0.571)\end{array}$ & \\
\hline Number of obs & 2,179 & & 2,179 & \\
\hline LR chi 2 & $2,149.950$ & & $2,144.680$ & \\
\hline Prob > chi2 & 0.000 & & 0.000 & \\
\hline Pseudo R2 & 0.713 & & 0.712 & \\
\hline
\end{tabular}

Source: Authors' calculations based on IFLS data $(2014) * \mathrm{p}<0.10,{ }^{* *} \mathrm{p}<0.05,{ }^{* * *} \mathrm{p}<0.01$. Standard errors are in parentheses. All standard errors were 